\title{
Diabetes in Pregnancy: Fetal Macrosomia, Hyperinsulinism, and Islet Hyperplasia in the Offspring of Rats Subjected to Temporary Protein-Energy Malnutrition Early in Life
}

\author{
ULF J. ERIKSSON AND INGEMAR SWENNE
}

Departments of Medical Cell Biology [U.J.E.] and Paediatrics [I.S.], University of Uppsala, Uppsala, Sweden

\begin{abstract}
The effect of temporary, severe proteinenergy malnutrition in young female rats on the fetal and maternal outcome of subsequent pregnancy has been investigated. Female rats were fed a low-protein diet between 3 and 6 wk of age. During this period, growth was stunted, glucose tolerance impaired, and insulin secretory response to glucose almost absent. Upon refeeding normal diet, growth was resumed and glucose tolerance normalized, but a subnormal insulin secretory response to glucose and a reduced pancreatic B-cell mass persisted into adult life. During pregnancy, such rats had a glucose tolerance with wide excursions of the serum glucose concentrations and an exaggerated insulin secretory response compared with normal rats. The previously malnourished rats also expanded their B-cell mass during pregnancy to the level of normal rats. The incidence of fetal loss and malformations was not increased in the offspring of previously malnourished rats. At term, the viable offspring were heavier than those of normal rats and had an increased pancreatic insulin content and an increased pancreatic B-cell mass. It is concluded that temporary protein-energy malnutrition in young rats reduces the ability to increase insulin production to meet the needs of pregnancy. The capacity for glucose disposal is decreased and glucose and other nutrients are transferred to the fetus in increased amounts. This stimulates pancreatic B-cell growth and the development of macrosomia in the offspring, well recognized features of diabetic pregnancy. The long-term consequences of malnutrition are thus not restricted to the malnourished but may also be inflicted on subsequent generations. (Pediatr Res 34: 791-795, 1993)
\end{abstract}

Abbreviations

$\mathbf{N}$, normal

LP, low protein

GTT, glucose tolerance test

In many parts of the third world, malnutrition and diseases related to the acute phase of malnutrition are a major pediatric

Received December 15, 1992; accepted July 13, 1993.

Correspondence and reprint requests: Dr. Ulf J. Eriksson, Department of Medical Cell Biology, University of Uppsala, Biomedicum, P. O. Box 571, S-751 23 Uppsala, Sweden.

Supported by The Swedish Diabetes Association, The Bank of Sweden Tercentenary Foundation, The Expressen Prenatal Research Foundation, The Juvenile Diabetes Foundation, The Nordisk Insulin Foundation Committee. The Swedish Hoechst Diabetes Fund, The Swedish Society for Medical Sciences, The Ernfors Family Fund, and The Swedish Medical Research Council (Grant Nos. 12X-7475, and 12P-9314). health problem. Feeding the malnourished brings about rapid recovery, but the full potential for physical growth and intellectual development may not be achieved even in the long term (1, 2 ). It is conceivable that malnutrition causes persisting structural damage and subnormal function in individual organs, but this notion has surprisingly not been fully investigated.

We have pursued the hypothesis that protein-energy malnutrition in the young may predispose for malnutrition-related diabetes in the adult $(3,4)$. There is considerable epidemiologic evidence to suggest such a relationship, but the pathogenic mechanisms are as yet unclear (5). We have, however, demonstrated that severe, but temporary, protein-energy malnutrition in the young rat leaves the adult smaller in size and with a diminished capacity for insulin production $(6,7)$. Diabetes does not develop spontaneously in these rats, but it can be speculated that normal glucose homeostasis cannot be maintained if demands on insulin secretion increase. We report here maternal and fetal outcome of pregnancy in previously malnourished rats of a colony with a documented increased rate of congenital malformations and embryonic-fetal resorptions in response to manifest diabetes in the mother $(8,9)$.

\section{MATERIALS AND METHODS}

Diets. Pelleted semisynthetic diet was made by Ewos, Södertälje, Sweden, as previously described in detail (10). It contained $5 \%$ protein (LP diet) and casein was used as the protein source. Methionine, the limiting amino acid of casein, was added to obviate acute deficiencies of this dietary constituent. The low protein content was compensated for by increasing the proportion of carbohydrate.

The commercially available rat food $\mathbf{R} 3$ (Ewos; $\mathrm{N}$ diet) used contained $18 \%$ protein, $5 \%$ fat, $52 \%$ carbohydrate, and $3.5 \%$ fiber. The R3 diet supports growth and development to the same extent as a semisynthetic diet with $15 \%$ protein made from the same constituents as the LP diet (11).

Animals. Sprague-Dawley rats were obtained from a local breeding colony (Biomedicum, University of Uppsala, Uppsala, Sweden). This colony has been extensively characterized with regard to its predisposition to produce malformations in the offspring if the mother is diabetic during pregnancy $(8,9,12)$. The animals had free access to $\mathrm{N}$ diet and tap water throughout breeding, pregnancy, and lactation. Male rats were caged overnight with females and pregnancy confirmed by the presence of sperm in vaginal smears on the following morning, which was designated d 0 of pregnancy. Pregnant rats were caged individually and spontaneous delivery took place on $d 22$ of pregnancy. The day after delivery, large litters were reduced to 12 pups. Litters of less than six were not used. At $21 \mathrm{~d}$ of age, young rats were weaned onto either LP diet (LP rats) or $\mathrm{N}$ diet ( $\mathrm{N}$ rats). The diets were fed ad libitum and after $3 \mathrm{wk}$, at the age of $6 \mathrm{wk}, \mathrm{LP}$ 
rats were returned to $\mathrm{N}$ diet and remained on this diet until the end of the experiment. Rats fed the LP diet reduced their food intake to one third of the amount consumed by $\mathbf{N}$ rats (Swenne I, Crace CJ, unpublished observations). The deficiency state induced should therefore be regarded as a combined proteinenergy malnutrition rather than as a pure protein deficiency (13, 14).

Pregnancy. Preliminary experiments suggested that female rats fed the LP diet between 3 and 6 wk of age were fertile at $12 \mathrm{wk}$ of age and could give birth to viable offspring. Groups of 14- to 17-wk-old female $\mathbf{N}$ and LP rats underwent an intraperitoneal GTT before mating. The animals were weighed and injected intraperitoneally with glucose $(2 \mathrm{~g} / \mathrm{kg}$ body weight $)$ without prior fasting between 0900 and $1200 \mathrm{~h}$. Blood samples were obtained from the cut tip of the tail before and 30,60, and 120 min after the glucose injection. Serum was separated and stored frozen at $-20^{\circ} \mathrm{C}$ until analyzed. After the GTT, the rats were mated as described above. During pregnancy, the animals had free access to tap water and $\mathrm{N}$ diet. The GTT was repeated on d 19 of pregnancy.

On d 20 of pregnancy, the rats were killed by cervical dislocation. The uterus was rapidly opened, the fetuses and placentas counted, the fetuses examined for externally visible malformations, and the uterine cavity searched for absorbed fetuses. All viable fetuses and their placentas were individually weighed and the average fetal and placental weight for each litter calculated. Blood samples were obtained from the cut neck vessels of one fetus from each mother. The pancreas was dissected from additional fetuses, weighed, and either fixed for histologic examination or extracted for determination of its insulin content (see below). Finally, the pancreas of the mother was dissected and fixed for histologic examination.

Analysis of insulin and glucose. To determine the total insulin content of the fetal pancreas, whole glands were finely chopped and disrupted ultrasonically in $300 \mu \mathrm{L}$ of acid ethanol $(1.5 \mathrm{~mL}$ of $12 \mathrm{M} \mathrm{HCl} / 100 \mathrm{~mL}$ of ethanol). The disrupted glands were extracted overnight at $4^{\circ} \mathrm{C}$ and centrifuged, and the supernatant was stored at $-20^{\circ} \mathrm{C}$ until analyzed.

Insulin in serum samples and pancreatic extracts was determined by RIA (15) using mouse insulin standard. Serum glucose was measured in a semiautomatic glucose analyzer (Glucose Analyzer II, Beckman Instruments, Fullerton, CA) using the glucose oxidase method.

Light microscopy and morphometry. Pancreatic glands for light microscopic investigation were obtained from $\mathrm{N}$ and LP rat mothers on d 20 of pregnancy and from their fetuses. For comparison, glands were also obtained from a separate group of virgin female 12-wk-old $\mathrm{N}$ and LP rats. The pancreatic glands were carefully dissected free from surrounding tissues, weighed, and fixed by immersion in Bouin's fluid. The fixed tissue was dehydrated in graded ethanol and embedded in paraffin according to a standardized protocol. Entire pancreatic glands were sectioned (see below) into 7- $\mu \mathrm{m}$-thick sections and mounted on glass slides. Insulin was stained in deparaffinized sections according to the unlabeled peroxidase-antiperoxidase method (16). The primary antibody was raised in guinea pigs against bovine insulin (Miles-Yeda Ltd., Elkhart, IN). Secondary antibodies and peroxidase-antiperoxidase complexes were from Dakopatts (Hägersten, Sweden). Immunologically bound peroxidase was visualized by incubation in diaminobenzidine tetrahydrochloride $(0.2 \mathrm{~g} / \mathrm{L}$; Polysciences Ltd., Warrington, PA) and hydrogen peroxide $(0.005 \%$, vol/vol). The immunostained sections were lightly counterstained with hematoxylin, dehydrated, and mounted.

The specificity of the immunostaining was tested according to Goldman (17) and included the application of antisera adsorbed with insulin, glucagon, somatostatin, and pancreatic polypeptide.

For estimation of pancreatic B-cell volume density, preliminary investigations indicated that six to seven sections should be measured in each gland to minimize variation due to random differences between individual sections. The sections were ob- tained at regular intervals throughout the pancreatic glands to avoid bias due to regional variation in islet cell composition and distribution (18). To obtain such samples, entire glands were sectioned. In adult rat pancreas, 150 sections were discarded for every section mounted and stained. In the fetal pancreas, the sampling interval was 25 sections. This procedure yielded about six to eight sections from each adult pancreas and five to seven sections from each fetal pancreas for morphometric analysis.

Pancreatic B-cell volume density, or the volumetric fraction of B-cells in the pancreas, was measured by planimetric analysis in a MOP-videoplan image analysis system (Kontron Bildanalyse, Munich, Germany) fitted with a Leitz microscope and a color monitor. The sections were first scanned at a magnification of $32 \times$ to determine the total area of pancreatic tissue and the area of nonpancreatic tissue, mostly lymph nodes and adipose tissue. The sections were subsequently scanned at a magnification of $100 \times$ and the area of insulin-positive cells measured.

Crude pancreatic weight was corrected for the proportion of nonpancreatic tissue in the sections. On the assumption that endocrine and exocrine tissue differ little in density (19), the Bcell weight was calculated from the corrected pancreatic weight and the B-cell volume density. To allow comparison between animals of different sizes, B-cell weight was finally expressed per unit body weight.

Statistics. Values are given as means \pm SEM for the number of rats studied. Two-tailed $t$ test for independent observations or a $\chi^{2}$ test was used for comparisons between $\mathrm{N}$ and LP rats and their offspring.

Experimental conditions. All experimental procedures as well as the treatment and housing of the animals were approved by the Animal Ethical Committee of the Medical Faculty of the University of Uppsala.

\section{RESULTS}

Maternal outcome. Nonpregnant N rats weighed slightly more $(247 \pm 4 \mathrm{~g}, n=11)$ than LP rats $(231 \pm 4 \mathrm{~g}, n=11)$ at the first GTT $(p<0.05)$. LP rats thrived during pregnancy and increased in weight as much as $\mathrm{N}$ rats; thus, the slight difference in maternal weight remained (weight on d 19 of pregnancy: $N$ rats $364 \pm 5$ g, LP rats $341 \pm 6 \mathrm{~g}, p<0.01$ ).

The prepregnancy GTT revealed no differences in glucose tolerance between N and LP rats (Fig. 1). The insulin secretory response to glucose was lower in LP rats at $30 \mathrm{~min}$ after the glucose injection but otherwise similar to that of $\mathrm{N}$ rats (Fig. 1). These observations are similar to our previous data on glucose tolerance and insulin secretory response to glucose in adult LP rats (6). On d 19 of pregnancy, $N$ rats had a lower basal serum glucose concentration and after glucose injection a flatter glucose curve than before pregnancy (compare upper panels of Figs. 1 and 2). The basal serum insulin concentration and insulin secretory response to glucose of $\mathrm{N}$ rats were not significantly altered by pregnancy, although a tendency toward an increased peak insulin concentration at 30 min could be observed on gestational d 19 (Figs. 1 and 2, lower panels).

Compared with before pregnancy, LP rats had a lower basal serum glucose concentration on d 19 of pregnancy (Figs. 1 and 2). The serum glucose concentration rose rapidly to levels similar to the prepregnancy GTT $30 \mathrm{~min}$ after the glucose injection and then returned to below prepregnancy levels. Compared with before pregnancy, basal serum insulin concentrations had increased in LP rats on 19 of pregnancy. There was now a prompt insulin secretory response $30 \mathrm{~min}$ after the glucose injection and serum insulin concentrations subsequently remained twice as high as before pregnancy (Figs. 1 and 2). Compared with pregnant $\mathbf{N}$ rats, the basal serum insulin concentration was twice as high in pregnant LP rats. The peak insulin secretory response was of the same magnitude in pregnant $\mathrm{N}$ and LP rats, whereas for the remainder of the GTT the serum insulin concentration was more than twice as high in the LP rats (Fig. 2). 

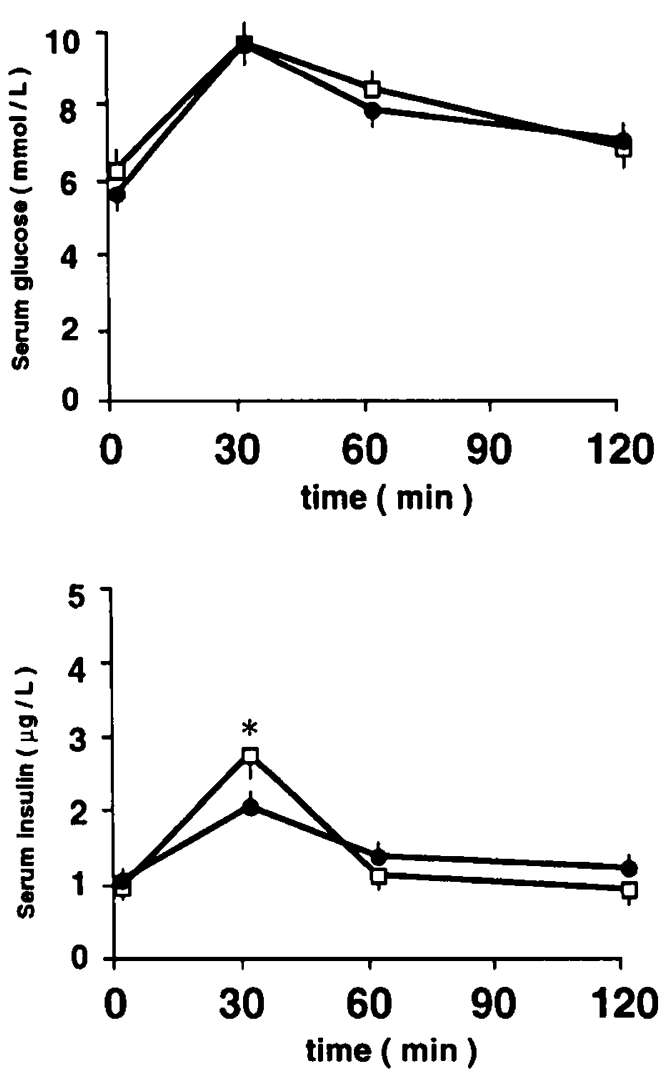

Fig. 1. Results of an intraperitoneal GTT $(2 \mathrm{~g}$ glucose $/ \mathrm{kg}$ body weight) performed before mating 14- to 17-wk-old N ( $\square$ ) and LP $(O)$ rats. Values are given as means \pm SEM for 11 rats in each group. ${ }^{*}, p<$ 0.05 , significant difference between $\mathrm{N}$ and LP rats by two-tailed $t$ test.

The pancreatic glands of 12-wk-old virgin rats and pregnant rats on d 20 of gestation had a well-preserved exocrine and endocrine morphology. In the pancreas of virgin rats, islets of Langerhans were distinctly outlined from the surrounding exocrine parenchyma. The central parts of the islets were deeply stained for insulin and surrounded by insulin-negative endocrine cells. Pancreatic sections from N and LP rats could not with certainty be distinguished from each other by qualitative assessment only. In the pancreas of pregnant rats, the outline of the islets was irregular and diffuse. The central parts of the islets stained distinctly for insulin and individual B-cells appeared larger compared with those of virgin rats. As with virgin rats, pancreatic sections from pregnant $\mathrm{N}$ and LP rats could not be distinguished from each other by qualitative examination.

Of the virgin rats used for morphometric analysis of the endocrine pancreas, the LP rats were slightly lighter than the N rats (Table 1). The B-cell volume density of the LP rats was $80 \%$ that of the $\mathrm{N}$ rats, and total B-cell mass and B-cell mass per unit body weight was reduced to two thirds that of $N$ rats. On $d 20$ of pregnancy, total B-cell mass of $\mathrm{N}$ rats did not differ from that of virgin rats. Because body weight increased considerably during pregnancy, B-cell mass per unit body weight had decreased $(p<$ $0.001)$. On the other hand, total B-cell mass of pregnant LP rats was greater than before pregnancy $(p<0.001)$ and did not differ from that of pregnant $\mathrm{N}$ rats. B-cell mass per unit body weight did not differ between $N$ and LP rats at the end of pregnancy.

Fetal outcome. Litter size and the proportion of viable offspring on $\mathrm{d} 20$ of pregnancy were similar in $\mathrm{N}$ and LP rats (Table 2 ). The proportions of absorbed fetuses or fetuses with external malformations were not increased in the pregnant LP rats. The malformations observed were two cases of sacral dysgenesis among the fetuses of $\mathrm{N}$ rats ( $\mathrm{N}$ fetuses) and one case each of omphalocele and one of sacral dysgenesis among the fetuses of $L P$ rats ( $L P$ fetuses).
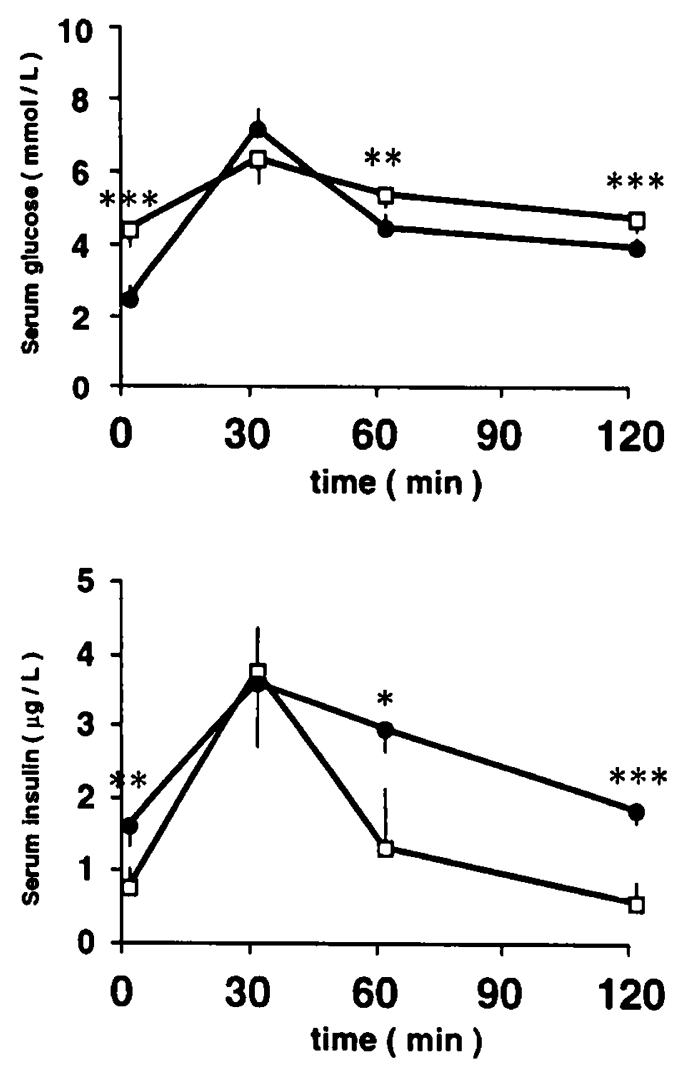

Fig. 2. Results of a second GTT performed on d 19 of pregnancy ( $\square$, $\mathrm{N}$ rats; $\bullet, L P$ rats). Values are given as means \pm SEM for 11 rats in each group. Significance of difference between $\mathrm{N}$ and LP rats by two-tailed $t$ test: ${ }^{*}, p<0.05 ;{ }^{* *}, p<0.01 ;{ }^{* * *}, p<0.001$.

Table 1. Pancreatic B-cell mass before and during pregnancy in female $N$ and LP rats*

\begin{tabular}{lccc}
\hline & $n$ & $\mathrm{~N}$ rats & LP rats \\
\hline Nonpregnant state & & & \\
$\quad$ Body weight (g) & 6 & $232 \pm 7$ & $205 \pm 6 \dagger$ \\
B-cell volume density (\%) & 6 & $0.57 \pm 0.02$ & $0.47 \pm 0.02 \ddagger$ \\
Pancreatic weight (mg) & 6 & $1199 \pm 37$ & $838 \pm 44 \S$ \\
B-cell weight (mg) & 6 & $6.8 \pm 0.2$ & $4.0 \pm 0.3 \S$ \\
B-cell weight/body weight $(\mu \mathrm{g} / \mathrm{g})$ & 6 & $29.2 \pm 0.9$ & $19.2 \pm 1.3 \S$ \\
Day 20 of pregnancy & & & \\
Body weight (g) & 11 & $364 \pm 5$ & $341 \pm 6 \ddagger$ \\
B-cell volume density (\%) & 11 & $0.54 \pm 0.02$ & $0.54 \pm 0.02$ \\
Pancreatic weight (mg) & 11 & $1193 \pm 30$ & $1208 \pm 35$ \\
B-cell weight (mg) & 11 & $6.4 \pm 0.4$ & $6.6 \pm 0.3$ \\
B-cell weight/body weight $(\mu \mathrm{g} / \mathrm{g})$ & 11 & $17.6 \pm 0.9$ & $19.2 \pm 0.9$ \\
\hline
\end{tabular}

* Pancreatic glands were obtained for morphometric analysis from 12-wk-old virgin rats and from pregnant rats on d 20 of gestation. Values are given as means \pm SEM. Significance of difference between $N$ and LP rats was determined by two-tailed $t$ test.

$+p<0.05$ vs $\mathrm{N}$ rats.

$\ddagger p<0.01$ vs $\mathrm{N}$ rats.

$\S p<0.001$ vs $\mathrm{N}$ rats.

The body weight of the LP fetuses was approximately $10 \%$ higher than that of the $\mathrm{N}$ fetuses, whereas no difference was observed in placental weight (Table 3). Serum glucose concentrations were similar and there was a tendency toward higher serum insulin concentrations in LP fetuses, although this did not reach statistical significance.

The amount of insulin in the pancreas of LP fetuses was increased by approximately two thirds compared with $\mathrm{N}$ fetuses regardless of whether it was expressed as total content, concentration in the pancreas, or content per unit body weight.

Light microscopic examination of the pancreatic glands of $\mathrm{N}$ 
Table 2. Outcome of pregnancy in female $N$ and LP rats*

\begin{tabular}{|c|c|c|}
\hline & $\mathrm{N}$ rats & LP rats \\
\hline Litters $(n)$ & 11 & 11 \\
\hline Implantations $(n)$ & 154 & 143 \\
\hline Resorptions $(n)$ & 8 & 14 \\
\hline (\%) & 5.2 & 9.8 \\
\hline Viable offspring $(n)$ & 146 & 129 \\
\hline$(\%)$ & 94.8 & 90.2 \\
\hline Malformations $(n)$ & 2 & 2 \\
\hline$(\%)$ & 1.4 & 1.6 \\
\hline
\end{tabular}

* Outcome was assessed on d 20 of pregnancy. No differences between $\mathrm{N}$ and LP rats were found $(p>0.05)$ by $\chi^{2}$ test.

Table 3. Fetal outcome on d 20 of pregnancy in N and LP rats*

\begin{tabular}{lccc}
\hline & $n$ & $\mathrm{~N}$ fetuses & LP fetuses \\
\hline Body weight $(\mathrm{g})$ & 11 & $3.51 \pm 0.05$ & $3.83 \pm 0.06 \dagger$ \\
Placental weight $(\mathrm{g})$ & 11 & $0.53 \pm 0.01$ & $0.50 \pm 0.01$ \\
Serum glucose $(\mathrm{mmol} / \mathrm{L})$ & 11 & $2.39 \pm 0.45$ & $2.28 \pm 0.15$ \\
Serum insulin $(\mu \mathrm{g} / \mathrm{L})$ & 11 & $5.74 \pm 1.53$ & $8.04 \pm 0.54$ \\
P-I content $(\mathrm{ng})$ & 11 & $645 \pm 51$ & $1150 \pm 71 \dagger$ \\
P-I concentration $(\mathrm{ng} / \mathrm{mg})$ & 11 & $46 \pm 5$ & $77 \pm 9 \dagger$ \\
P-I content/body weight $(\mathrm{ng} / \mathrm{g})$ & 11 & $181 \pm 14$ & $308 \pm 25 \dagger$ \\
B-cell volume density $(\%)$ & 6 & $0.51 \pm 0.03$ & $0.72 \pm 0.03 \dagger$ \\
B-cell weight $(\mu \mathrm{g})$ & 6 & $71 \pm 5$ & $106 \pm 7 \ddagger$ \\
B-cell weight/body weight $(\mu \mathrm{g} / \mathrm{g})$ & 6 & $19.2 \pm 1.1$ & $26.5 \pm 1.8 \dagger$ \\
\hline
\end{tabular}

* Values are given as means \pm SEM. P-I, pancreatic insulin.

$\dagger p<0.001$ vs $\mathrm{N}$ fetuses by two-tailed $t$ test.

$\ddagger p<0.01$ vs $\mathrm{N}$ fetuses by two-tailed $t$ test.

and LP fetuses showed a well-preserved pancreatic exocrine and endocrine morphology. The islets of Langerhans were composed of a core of darkly stained B cells surrounded by a fringe, often wide, of unstained endocrine cells that was poorly delineated against the surrounding parenchyma. Occasionally, insulin-positive cells could be seen in the pancreatic ducts. The pancreatic islets of the LP fetuses usually appeared larger and more numerous than those of $\mathrm{N}$ fetuses, but the origin of individual tissue sections could not with certainty be established by qualitative examination.

Morphometric analysis of the fetal pancreas demonstrated an increase by $40 \%$ of pancreatic B-cell volume density in LP fetuses compared with $\mathrm{N}$ fetuses (Table 3). The total B-cell mass and the B-cell mass per unit body weight of the LP fetuses were increased by the same order of magnitude.

\section{DISCUSSION}

During pregnancy, there is a decreased disposal of glucose and other nutrients in the mother. Circulating substrate levels are kept high and an abundant supply is available to the growing fetus. However, to control metabolism and avoid the development of impaired glucose tolerance or even diabetes, which would adversely affect the fetus, maternal insulin levels have to be increased (20). In normal rat pregnancy, glucose tolerance is normal or only slightly impaired but at the cost of an increased insulin secretion (21-24), which compensates for an increased peripheral resistance to the actions of insulin $(22,24,25)$. To meet this increased demand for insulin production, the sensitivity to glucose of insulin biosynthesis and secretion is increased during pregnancy $(26,27)$. Moreover, islet cell proliferation peaks in midpregnancy (28) and total B-cell mass is increased by the end of pregnancy $(28-32)$. The pregnant $\mathrm{N}$ rats of the present study maintained a normal glucose tolerance and had an enhanced insulin secretory response to glucose. They did not, however, increase B-cell mass, which is at variance with previous investigations. The reason for this discrepancy is unclear, but it should be noted that the increase of the insulin secretory response is not of the magnitude observed in other investigations $(22,23)$.
It could be that the glycemic stimulation to increase insulin output is low during pregnancy in the rats of the studied colony compared with rats from other colonies. Moreover, the expansion of B-cell mass peaks before $\mathrm{d} 20$ of pregnancy and is followed by a decrease toward term (28). With the present experimental design, a modest increase of B-cell mass during midpregnancy may be missed.

Nonpregnant LP rats have a blunted insulin secretory response to glucose (11), a decreased B-cell mass (7), and an increased peripheral sensitivity to insulin (33), which interact to yield a normal glucose tolerance. On d 20 of pregnancy, however, LP rats had a normal peak insulin secretory response followed by an increased prolonged response that caused a rebound of the serum glucose concentration to values lower than those of $\mathbf{N}$ rats. Moreover, the growth during pregnancy of the total B-cell mass of LP rats exceeds the B-cell growth of $N$ rats. These observations would indicate an ability of the endocrine pancreas of LP rats to increase insulin output during pregnancy. However, the major observations of the present study are the increased body weight and the increased pancreatic insulin content and Bcell mass of LP fetuses, which are features commonly seen in infants of diabetic mothers (34). The small differences of glucose tolerance and insulin secretion observed in pregnant LP rats compared with pregnant $\mathrm{N}$ rats would thus be sufficient to increase maternal substrate availability and transfer to the fetus, which in turn stimulate fetal B cells and the development of macrosomia. Another characteristic of diabetic pregnancy, the increased incidence of fetal dysmorphogenesis, was not found in the present study, inasmuch as the rates of resorptions and malformations were not increased in the offspring of LP rats. The period of susceptibility to malformations, however, occurs early in pregnancy (35-37), and maternal metabolism may not have been disturbed at this point of development. Alternatively, the severe forms of fetal maldevelopment resulting in resorptions and malformations may require a grave maternal metabolic derangement that was not present in the pregnant LP rats of this study (38).

It has long been a question of controversy as to whether the hyperinsulinism and macrosomia of the infants of diabetic mothers can be reproduced in the rat. It would appear that severe diabetes, with considerable hyperglycemia and wasting of the mother, causes fetal growth retardation (39-45) and poor development of the endocrine pancreas (46-49). On the other hand, the mild disturbance of glucose tolerance observed in this study or even mild experimental diabetes during pregnancy results in large offspring and enhanced development of the fetal pancreatic B cell (50-54). A possible dividing line between "severe" and "mild" diabetes in this context could be the function of maternal B cells. In severe diabetes, residual maternal B-cell mass is small and does not expand during pregnancy (31). In experimental diabetes with a less disturbed glucose metabolism, B-cell mass is larger and retains the capacity to grow during pregnancy (55). This ability, presently observed in LP rats, would help limit further decompensation of metabolism during pregnancy and thereby restrict adverse effects on the fetus.

The present investigation demonstrates that previously malnourished rats with a decreased capacity for insulin production cannot maintain normal glucose metabolism during pregnancy. Although the metabolic derangements appear mild, they are sufficient to influence fetal growth and fetal endocrine pancreatic development. Persisting adverse effects of protein-energy malnutrition are thus not limited to the malnourished but can also affect subsequent generations. The glucose metabolism of adult offspring of LP rats therefore remains to be investigated. In this context, it is interesting to note that a perturbed intrauterine environment can influence B-cell function and peripheral sensitivity to the actions of insulin not only in the short term. It can also confer a lifelong predisposition for an impaired glucose tolerance and even diabetes mellitus (56-62). 
Acknowledgments. The authors thank Marina Papazians, Eva Törnelius, and Parri Wentzel for excellent technical assistance. They are also indebted to Associate Professor Valdemar Grill, Department of Endocrinology, Karolinska Hospital, Stockholm for assistance with the determinations of serum insulin.

\section{REFERENCES}

1. Galler JR, Ramsey FC, Salt P, Archer E 1987 Long-term effects of early kwashiorkor compared with marasmus. I. Physical growth and sexual maturation. J Pediatr Gastroenterol Nutr 6:841-846

2. Galler JR, Ramsey FC, Morley DS, Archer E, Salt P 1990 The long-term effects of early kwashiorkor compared with marasmus. IV. Performance on the national high school entrance examination. Pediatr Res 28:235-239

3. WHO Study Group 1985 Diabetes Mellitus (Technical Report Series 727). World Health Organization, Geneva, pp 20-25

4. Rao RH 1988 Diabetes in the undernourished: coincidence or consequence? Endocr Rev 9:67-87

5. Abu-Bakare A, Gill GV, Taylor R, Alberti KGMM 1986 Tropical or malnutrition-related diabetes: a real syndrome? Lancet 1:1135-1138

6. Swenne I, Crace CJ, Milner RDG 1987 Persistent impairment of insulin secretory response to glucose in adult rats after limited period of proteincalorie malnutrition early in life. Diabetes 36:454-458

7. Swenne I, Borg LAH, Crace CJ, Schnell Landström AS 1992 Persistent reduction of pancreatic B-cell mass after a limited period of protein-energy malnutrition in the young rat. Diabetologia 35:939-945

8. Eriksson UJ, Dahlström E, Larsson KS, Hellerström C 1982 Increased incidence of congenital malformations in the offspring of diabetic rats and their prevention by maternal insulin therapy. Diabetes 31:1-6

9. Eriksson UJ 1984 Diabetes in pregnancy: retarded fetal growth, congenital malformations and feto-maternal concentrations of zinc, copper and manganese in the rat. J Nutr 114:477-486

10. Syme G 1982 The effect of protein-deficient isoenergetic diets on the growth of rat jejunal mucosa. Br J Nutr 48:25-36

11. Swenne I, Crace CJ, Jansson L 1988 Intermittent protein-calorie malnutrition in the young rat causes long-term impairment of the insulin secretory response to glucose in vitro. J Endocrinol 118:295-302

12. Eriksson UJ 1988 Importance of genetic predisposition and maternal environment for the occurrence of congenital malformations in offspring of diabetic rats. Teratology 37:365-374

13. Cabak V, Dickerson JWT, Widdowson EM 1963 Response of young rats to deprivation of protein or of calories. Br J Nutr 17:601-616

14. Hill DE, Holt AB, Parra A, Cheek DB 1970 The influence of protein-calorie versus calorie restriction on the body composition and cellular growth of muscle and liver in weanling rats. Johns Hopkins Med J 127:146-163

15. Heding $\mathbf{L} 1972$ Determination of total serum insulin (IRI) in insulin-treated patients. Diabetologia 8:260-266

16. Erlandsen SL, Parsons JA, Burke JP, Redick JA, Van Orden DE, Van Orden LS 1975 A modification of the unlabeled antibody enzyme method using heterologous antisera for the light microscopic and ultrastructural localization of insulin, glucagon and growth hormone. J Histochem Cytochem 23:666-677

17. Goldman M 1968 Fluorescent Antibody Methods. Academic Press, New York, pp 153-172

18. Orci L, Baetens D, Ravazzola M, Stefan Y, Malaisse-Lagae F 1976 Pancreatic polypeptide and glucagon: non-random distribution in pancreatic islets. Life Sci 19:1811-1816

19. Buitrago A, Gylfe E, Henriksson C, Pertoft H 1977 Rapid isolation of pancreatic islets from collagenase digested pancreas by sedimentation through Percoll ${ }^{\circ}$ at unit gravity. Biochem Biophys Res Commun 79:823-828

20. Freinkel $N 1980$ Of pregnancy and progeny. Diabetes 29:1023-1035

21. Costrini NV, Kalkhoff RK 1971 Relative effects of pregnancy, estradiol, and progesterone on plasma insulin and pancreatic insulin secretion. J Clin Invest 50:992-999

22. Leturque A, Ferre P, Satabin P, Kervran A, Girard J 1980 In vivo insulin resistance during pregnancy in the rat. Diabetologia 19:521-528

23. Davidson MB 1984 Insulin resistance of late pregnancy does not include the liver. Metabolism 33:532-537

24. Martin A, Zorzano A, Caruncho I, Herrera E 1986 Glucose tolerance tests and "in vivo" response to intravenous insulin in the unanaesthesized late pregnant rat and their consequences to the fetus. Diabete Metab 12:303-307

25. Knopp RH, Ruder HJ, Herrera E, Freinkel N 1970 Carbohydrate metabolism in pregnancy. VII. Insulin tolerance during late pregnancy in the fed and fasted rat. Acta Endocrinol 65:352-360

26. Green IC, Taylor KW 1972 Effects of pregnancy in the rat on the size and insulin secretory response of the islets of Langerhans. J Endocrinol 54:317325

27. Bone AJ, Howell SL 1977 Alterations in regulation of insulin biosynthesis in pregnancy and starvation in isolated rat islets of Langerhans. Biochem J 166:501-507

28. Dunger A, Lucke S, Besch W, Hahn H-J 1989 The rat pancreatic B-cell during pregnancy and after delivery. Int J Feto-Maternal Med 2:55-61

29. Hellerström $C 1963$ The influence of pregnancy and lactation on the endocrine pancreas of mice. Acta Soc Med Ups 68:17-28

30. Van Assche FA 1974 Quantitative morphologic and histoenzymatic study of the endocrine pancreas in non-pregnant and pregnant rats. Am J Obstet Gynecol 118:39-41

31. Van Assche FA, Gepts W, Aerts L 1980 Immunocytochemical study of the endocrine pancreas in the rat during normal pregnancy and during experimental diabetic pregnancy. Diabetologia 18:487-491

32. Marynissen G, Aerts L, van Assche FA 1983 The endocrine pancreas during pregnancy and lactation in the rat. J Dev Physiol 5:373-381

33. Escriva F, Kergoat M, Bailbé D, Pascual-Leone AM, Portha B 1991 Increased insulin action in the rat after protein malnutrition early in life. Diabetologia 34:559-564

34. Pedersen J 1977 The Pregnant Diabetic and Her Newborn, 2nd Ed. Munksgaard, Copenhagen

35. Baker L, Egler JM, Klein SH, Goldman AS 1981 Meticulous control of diabetes during organogenesis prevents congenital lumbosacral defects in rats. Diabetes 30:955-959

36. Eriksson RSM, Thunberg L, Eriksson UJ 1989 Effects of interrupted insulin treatment on fetal outcome of pregnant diabetic rats. Diabetes 38:764-772

37. Eriksson UJ, Bone AJ, Turnbull DM, Baird JD 1989 Timed interruption of insulin therapy in diabetic BB/E rat pregnancy: effects on maternal metabolism and fetal outcome. Acta Endocrinol (Copenh) 120:800-810

38. Eriksson UJ, Borg LAH, Forsberg H, Styrud J 1991 Diabetic embryopathy: studies with animal and in vitro models. Diabetes 40 (suppl 2):94-98

39. Kim JN, Runge W, Wells L, Lazarow A 1960 Effects of experimental diabetes on the offspring of the rat. Fetal growth, birth, weight, gestation period and fetal mortality. Diabetes 9:396-404

40. Sybulski S, Maughan GB 1971 Use of streptozotocin as a diabetic agent in pregnant rats. Endocrinology 89:1537-1540

41. Eriksson UJ, Andersson A, Efendic S, Elde R, Hellerström C 1980 Diabetes in pregnancy: effects on the fetal and newborn rat with particular regard to body weight, serum insulin concentration and pancreatic contents of insulin, glucagon and somatostatin. Acta Endocrinol (Copenh) 94:354-364

42. Brownscheidle CM, Wootten V, Mathieu MH, Davis DL, Hofman IA 1983 The effects of maternal diabetes on fetal maturation and neonatal health. Metabolism 32 (suppl 1):148-155

43. Eriksson UJ, Lewis N, Freinkel N 1984 Growth retardation during early organogenesis in embryos of experimentally diabetic rats. Diabetes 33:281 284

44. Uriu-Hare JY, Stern JS, Reaven GM, Keen CL 1985 The effect of maternal diabetes on trace element status and fetal development in the rat. Diabetes 34:1031-1040

45. Giavini E, Brocca ML, Prati M, Roversi GD, Vismara C 1986 Effects of streptozotocin-induced diabetes on fetal development of the rat. Teratology 34:81-88

46. Dixit PK, Lowe IP, Heggestad CB, Lazarow A 1964 Insulin content of microdissected fetal islets obtained from diabetic and normal rats. Diabetes 13:71-77

47. Golob EK, Rishi S, Becker KL, Moore C, Shah H 1970 Effect of streptozotocininduced diabetes on pancreatic insulin content of the fetus. Diabetes 19:610613

48. Eriksson UJ, Swenne I 1982 Diabetes and pregnancy: growth of the fetal pancreatic B-cells in the rat. Biol Neonate 42:239-248

49. Swenne I, Eriksson UJ 1982 Diabetes and pregnancy: islet cell proliferation in fetal rat pancreas. Diabetologia 23:525-528

50. Solomon F 1959 Embryomegaly and increased fetal mortality in pregnant rats with mild alloxan diabetes. Diabetes 8:45-50

51. Lazarow A, Kim JN, Wells LJ 1960 Birth weight and fetal mortality in pregnant subdiabetic rats. Diabetes 9:114-117

52. Pitkin RM, Planck CJ, Filer Jr LJ 1971 Fetal and placental composition in experimental maternal diabetes. Proc Soc Exp Biol Med 138:163-166

53. Aerts L, van Assche FA 1977 Rat fetal endocrine pancreas in experimental diabetes. J Endocrinol 73:339-346

54. Kervran A, Guillaume M, Jost A 1978 The endocrine pancreas of the fetus from diabetic pregnant rat. Diabetologia 15:387-393

55. Ziegler B, Lucke S, Besch W, Hahn H-J 1985 Pregnancy-associated changes in the endocrine pancreas of normoglycaemic streptozotocin-treated Wistar rats. Diabetologia 28:172-175

56. Aerts L, Sodoyez-Goffaux F, Sodoyez JC, Malaisse WJ, van Assche FA 1988 The diabetic intrauterine milieu has a long-lasting effect on insulin secretion by B-cells and on insulin uptake by target tissues. Am J Obstet Gynecol 159:1287-1292

57. Pettitt DJ, Aleck KA, Baird HR, Carraher MJ, Bennet PH, Knowler WC 1988 Congenital susceptibility to NIDDM. Role of intrauterine environment. Diabetes 37:622-628

58. Gaugier D, Bihoreau M-T, Ktorza A, Berthault M-F, Picon L 1990 Inheritance of diabetes mellitus as consequence of gestational hyperglycemia in rats. Diabetes 39:734-739

59. Susa JB, Boylan JM, Sehgal P, Schwartz R 1990 Impaired insulin secretion in the neonatal rhesus monkey after chronic hyperinsulinemia in utero. Proc Soc Exp Biol Med 194:209-215

60. Dahri S, Snoeck A, Reusens-Billen B, Remacle C, Hoet JJ 1991 Islet function in offspring of mothers on low-protein diet during gestation. Diabetes 40 (suppl 2):115-120

61. Grill V, Johansson B, Jalkanen P, Eriksson UJ 1991 Influence of severe diabetes mellitus early in pregnancy in the rat: effects on insulin sensitivity and insulin secretion in the offspring. Diabetologia 34:373-378

62. Hales CN, Barker DJP 1992 Type 2 (non-insulin-dependent) diabetes mellitus: the thrifty phenotype hypothesis. Diabetologia 35:595-560 